\title{
THE EFFECT OF BIG BOOKS AS TEACHING MEDIA ON THE THIRD GRADE STUDENTS' READING COMPREHENSION IN SOUTH BALI
}

\author{
Nalantha, I. M. D \\ English Language Education, UniversitasPendidikanGanesha \\ md.drati.nalantha@undiksha.ac.id \\ Artini, L. P \\ English Language Education, UniversitasPendidikanGanesha \\ putu.artini@undiksha.ac.id \\ Mahayanti, N.W.S \\ English Language Education, UniversitasPendidikanGanesha \\ surya.mahayanti@undiksha.ac.id
}

\begin{abstract}
This study aimed at investigating whether or not there was a significant effect of Big Book as teaching media on the third grade students' reading comprehension in south Bali. Research design of this study was Quasi Experimental of Post-test Only Control Group Design. The population was 56 students of the third grade students of elementary school in south Bali. Two classes were used as sample of this study. Class IIIA was assigned as experimental group and treated by using Big Book as teaching media. Meanwhile, class IIIB was assigned as control group and treated by using conventional media. The data were analyzed by using t-test through SPSS 16.0. The result of descriptive statistical analysis shows that mean score of experimental group is 80.5357 and control group is 75.3571. It means experimental group gets better score than in control group. The result of inferential statistical analysis shows comparison between $t_{\text {obs }}$ (t-observed) and $t_{c v}\left(t\right.$-critical value) that is $2.181>2.0049$. It means that the value of $t_{o b s}$ is higher than the value of $t_{\mathrm{cv}}$. It can be concluded that there is a significant effect on the third grade students' reading comprehension taught by using Big Book as teaching media.
\end{abstract}

Keywords: Big Book, teaching media, reading comprehension, young learner

\section{INTRODUCTION}

As a foreign language in Indonesia, English is seriously learned by many people to have a good communication and also to get more information of international world. It can be seen that English is learned by children from elementary school to get higher education. Therefore, our government seriously provides the appropriate curriculum about this subject. Further, English becomes one of subjects in elementary schools. By mastering English, students will be able to develop themselves intellectually, socially, and emotionally. Thus, there has to be many efforts to do in order to create an interesting English learning that can motivate students to increase their interest in learning English.

In teaching English, there are four important language skills that have to be taught to the students. They are listening, speaking, reading, and writing. From those four skills, reading has an important role in language learning. It is because the students can get an input of knowledge, information, ideas and enjoyment through reading. According to Seken (2013:3), reading is a process of comprehending texts to get information about what is being read and make them easy to find the world around them. Furthermore, by reading the students can get amount of new 
vocabulary that latter on can be applied in writing or speaking. Reading skill is an essential skill that has to be mastered by students in order to get success not only in English, but also in other subjects (Nunan 2003: 69). By strengthening reading skills, students will make the greater progress in all other areas of learning because most of other subjects basically involve reading. Moreover, reading becomes very important for students' skill in many aspects of life.

According to Harmer (1998:68), reading is important because of some reasons; first, in order to successfully gain access to new information for academic purposes, reading is useful for students' academic purpose, it is important to the students to learn reading in the classroom; second, reading helps language acquisition that make the students will acquire their language; third, students must read a lot to be able write good English because writing good English is not happened for instance reading text provides good models for English writing, and fourth, students will get many vocabularies from what they have read, so, through reading students can increase their vocabulary knowledge. According to Nunan (2003:68), the goal of reading is comprehension. Reading comprehension is the ability to understand what ones read. Reading comprehension has become the principal point in reading activity because someone can easily understand what they read if they can comprehend the text or passage well. In order to help students comprehend the text, teachers are very expected to be creative in teaching reading. There are many techniques, strategies, models, and media of teaching that can be used by the English teachers to teach reading. By using any appropriate strategy or media, it is very expected to help students be more attractive and understand the material well. Thus, a teacher has to be wise in choosing an appropriate way to teach reading based on the students' need especially for young learners.

Teaching English for young learners is different from teaching English for adults especially in teaching reading. Teaching English for young learners is quite difficult because we have to adapt to their interest. Further, in teaching English for young learners the teachers need to use media which is colorful and attractive to make students easy to understand the material. According to Harmer (2007) one of the characteristics of young learners is they have limited attention span and they are easy to get bored. It means that young learners have short time to pay attention to the teacher if the teachers cannot interest the young learners to study. In addition, the teachers have to be good in getting students attention and make the young learners can enjoy the lesson. Further, teachers have to use the appropriate media to make the learning process effective because a good media is needed to attract students' attention and make the students focus on the learning process.

Using media in teaching reading is important for attracting the attention of the students because media will help the teachers to create a good classroom situation (Wahyuni, 2013). According to Andi (2013), the advantages of using media in teaching are students have more motivation in learning, because the medium of teaching, learning activities will more attractive, with the medium of teaching and learning activities of students would be more ideas students bring to everyday life, and using media in teaching students to learn will be more concrete. Good media can make young learners developing their characters by involving them in the process of reading comprehension. One media that can be used in teaching reading is Big Book.

Big Book is kind of storybook that printed in large version and Big Book also as large format of printed book with texts and illustrations (Hall and O'connor, 2006). It is called as 'Big Book' because the book is enlarged version of children's book which is considered to be one of the most effective ways to get young learners attention through the size of the book itself. Hence, book as media that the teachers use can affect teacher and learning process in order to make the students understand the material. It supported by Brown (1980) that stated Big Book is large of colorful print with illustrations that allow whole classrooms to more understand about the content of the story or even stimulate students' imagination. Further, Lynch (2008: 35) found that Big Book creates secure and relaxed atmosphere in the classroom and attracts students' attention in teaching and learning process.

Furthermore, Big Book is different from the other ordinary book, it is showed from the characteristic of this book. In line with this, Big Book also a book that printed in the collorful book so it can increase the students interest in reading book. Reading a Big Book is one of the activities used to facilitate students' comprehension of a story delivered by the teacher (Rahim 
$\&$ Harun, 2010). The used of this in the learning process can give amount of advantages. One of the advantages, the use of Big Book can create fun and meaningful learning process. It can develop language and literacy among children because it facilitates the use of certain reading strategies such as shared reading or reading a loud that can make the children involve themselves during learning process.

In this research, Big Book which was used as teaching media was written by KetutAndiWiraprasta. The illustrator of Big Book was KomangJulawan. The size of Big Book was $29.7 \times 41.7 \mathrm{~cm}$ and it was divided $29.7 \times 33.2 \mathrm{~cm}$ for colored picture and $29.7 \times 8 \mathrm{~cm}$ for the illustration. There are four Big Books which were used in this study. These Big Books were developed in 2017 based on the syllabus for the third grade students in elementary school. The tittle of these Big Books are "I can be Fit" in the topic of food, "Trip to Grandma's House" in the topic of family, "Football Match" in the topic of parts of body, and "Bad Summer" in the topic of vegetables and fruits. These Big Books had not been implemented in order to know its effectiveness on students' reading comprehension. It was continued in this study. These Big Books were used in this study as teaching media in south Bali elementary school.

In 2013, there is a study on the use of Big Book which has been conducted by Fahmi, Suhartono, \&Arifin in the fifth grade students of SDN 32 Pontianak. This study focused on the use of Big Book in improving students' reading comprehension. The result of this study showed that the use of Big Book in improving students' reading comprehension could be seen in every meeting or cycles. It means that students' reading comprehension increased in every meeting because of Big Book.

Another research has been done by Mahayanti, Nitiasih, and Wiraprasta (2017) in SD Laboratorium UNDIKSHA Singaraja in developing Big Book in teaching English at the third grade students of elementary school in SD Laboratorium UNDIKSHA Singaraja in academic year 2017/2018. This study was Research and Development and the result of this study showed that the Big Book developed was categorized as excellent media. However, this Big Book has not been implemented in order to know its effectiveness on students' reading comprehension. It was implemented in current study.

Using Big Book as teaching media can influence students' reading comprehension and this statement is supported by Mahayanti, Artini, and Jannah's research (2017) in SD Laboratorium UNDIKSHA Singaraja in using Big Book as media in teaching English at fifth grade students based on the syllabus in SD Laboratorium UNDIKSHA Singaraja. This study was an experimental research, and the result of this study showed that there was a significant difference of reading comprehension achievement between students treated with Big Book as media and those treated using conventional media at fifth grade of elementary school in SD Laboratorium UNDIKSHA Singaraja. It means that Big Book as teaching media influence in improving students' reading comprehension in young learners.

The other research that is also supported Big Book as teaching media is conducted by Mahayanti and Asrina (2017) in SD Laboratorium UNDIKSHA Singaraja in using Big Book as media in teaching English at sixth grade students based on the syllabus in SD Laboratorium UNDIKSHA Singaraja. The result of this experimental study showed that there was a significant difference on the sixth grade students' reading comprehension between students taught by using Big Book as media and students taught by using conventional media.

Considering the power of Big Book as attractive teaching media in teaching reading comprehension for students, the purpose of this study was to investigate the significant effect of Big Book as teaching media on students' reading comprehension and how teaching and learning process during implementing Big Book as teaching media in teaching reading. This study was conducted in the third grade of elementary school in south Bali in academic year 2017/2018.

\section{METHOD}

This study was conducted in elementary school in south Bali. Research design of this study was Quasi Experimental of Post-test Only Control Group Design. The population was 56 students of the third grade students SDN 5 Sumerta Denpasar. Two classes were used as sample of this study. Class IIIA was assigned as experimental group and treated by using Big Book as teaching media. Meanwhile, class IIIB was assigned as control group and treated by using 
conventional media. The instruments used in this study were lesson plan and post-test. Lesson plan was used as guidance for the teacher in conducting the lesson. The lesson plan for experimental group was designed by using media named Big Book while lesson plan for control group was designed by using conventional media.Post-test was in the form of multiple choice written test in order to enable to measure students' reading comprehension. There were several items in the form of matching items which its function was just a guidance for students about vocabulary that would lead in reading the text. The result of the data would show whether or not there is a significant effect on students' reading comprehension which was taught by using media named Big Book, compared with conventional media.

\section{FINDINGS AND DISCUSSION}

In findings, there are three parts discussed, namely description of the data, requirement tests for hypothesis testing, and hypothesis testing. First, the result of description of the data showed that the mean score of experimental group was 80.5357 and the mean score of control group was 75.3571. It meant that the mean score of students in experimental group was significantly higher than the control group. It was indicated that reading comprehension of students in experimental group was better than reading comprehension of students in control group. Median of the experimental group was 80.0000 and median of the control group was 75.0000. It showed that middle score of the experimental group was higher than the control group. Mode of the experimental group was 80 , while mode of the control group was 80 . It could be assumed that the most frequently score appeared in the experimental group was same as in the control group. Standard deviation of the experimental group was 8.85472, while the standard deviation of the control group was 8.91613. It meant that the mean of students taught by using Big Book were better in describing all scores for group and represent the individuals in a group.

Second, the result of requirement tests for hypothesis testing showed that in testing for normal distribution, the significant value of the experimental group was 0.200 , and the significant value of the control group was 0.200 . The result of the normality test showed that the significant value (Sig.) of those two groups had exceeded the value of 0.05 . Considering the result of Kolmogorov-Smirnov statistic, it could be concluded that the data distribution in both of the groups were normally distributed. Further, in testing for homogeneity of variance, the significant value based on mean was 0.912 , based on median was 0.899 , based on median and with adjusted df was 0.899 , and based on trimmed mean was 0.946 . Considering the result of Levene statistic, it could be concluded that the variances between two groups were already homogenous.

Table 1. The Result of Independent Samples Test

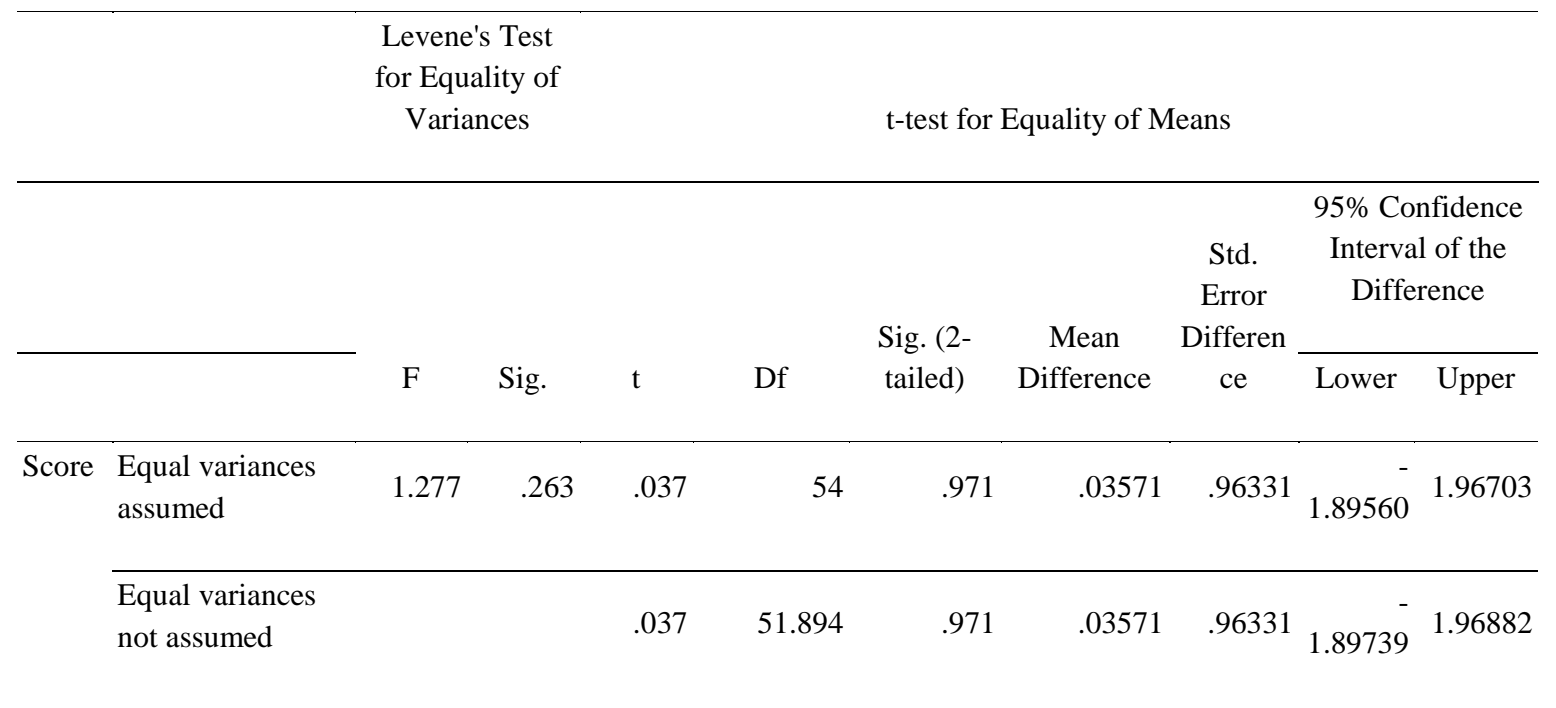


Third, the result of hypothesis testing showed the $t_{\text {obs }}$ was 2.181 . The $t$-critical value was observed by using table of critical value of the t-distribution. Based on Table, the t-critical value for $\mathrm{df}$ (degree of freedom) 54 in 0.05 was 2.0049. Therefore, the comparison between $t_{\mathrm{obs}}$ and $\mathrm{t}_{\mathrm{cv}}$ was $2.181>2.0049$. Since the value of $t_{o b s}$ was higher than the $t_{c v}$, then the null hypothesis was rejected (H0) and alternative hypothesis $(\mathrm{H} \alpha)$ was accepted. It meant that there was a significant effect on the third grade students' reading comprehension between students taught by using Big Book as teaching media and students taught by conventional media.

In this study, treatment was conducted eight times for experimental group and control group. The difference treatment between each group was the experimental group was treated by using Big Book as media and the control group was treated by using conventional media. There are four Big Books which were used in this study. The topic of the first Big Book was about family entitled Trip to Grandma's House. Then, the topic of the second Big Book was about food entitled I can be Fit. The topic of the third Big Book was about parts of body entitled Football Match. The topic of the fourth Big Book was about fruits and vegetables entitled Bad Summer.

There were some activities which were done by the researcher as stated by Fisher (1991) in applying the Big Book. There are pre-reading activity before reading big book, reading the complete story, rereading activity, after reading activity, and close activity. The implementation of Big Book as teaching media in this study was applied systematically based on the procedures which were stated by Fisher (1991).

The first activity in the implementation, students who were taught by using Big Book as teaching media were asked to pay attention to the teacher. Then, the researcher started the pre-reading activity before reading Big Book. In this pre-reading activity, the researcher introduced the parts of Big Book such as the front cover, pages, the upper part, and the bottom part of the Big Book, the back cover and how to open the book in the right way. The researcher saw that the students looked surprised to see the Big Book because it was their first time to see book with unusual size. Then, the researcher told the title of the book, the writer of the Big Book, and the illustrator of the Big Book loudly to increase students' information about Big Book. Then, the researcher asked the possible story of the Big Book based on the title and the illustration from the front cover of the book. This activity was used to activate the students' prior knowledge related to the Big Book. In this activity, the students try to say their opinion about the possible stories by looking at the picture in the front cover of the book. In implementing this activity, the students showed that they were very happy and enthusiastic to see the Big Book and in the same time, the researcher realized that Big Book could attract students' attention. This was related to statement by Nambiar (1991) who stated that one of the advantages of Big Book was Big Book can attract students' attention because of the unusual size. After the beginning activities were implemented, the researcher continued the implementation into the next activity.

In the second activity, the researcher red the complete story of the book. In implementing this activity, the researcher read the story continuously from the first page up to the last page in order to make the students familiar with the story and encourage them to read by themselves. The researcher read the story loudly with interesting expression and intonation and followed the text with the researcher's hand and pointer, by doing those students could see what researcher said and they learned to associate sound with the printed symbol. In several times, the researcher as the teacher stopped in certain page and asked the children to guess the text in the next page or give additional information about the story or the illustration. It made the students thought and imagined what the text in the next page would be. Furthermore, the students shared their opinion about what they though enthusiastically and the researcher gave response through the students' opinion and gave additional information about the story or the illustration of the Big Book to increase the students' knowledge about the story and help them to understand the story of the Big Book itself.

The third activity in the implementation, the researcher re-read the story of Big Book. In this activity, the researcher repeated story page by page and allowed the students to follow what the researcher said. In several times, the researcher stopped in a certain page if there was difficult word that the students did not understand. Then, the teacher showed the words and said it clearly to the students. It would made the students familiar with the meaning of the words and it helped the students in understand the story. The researcher asked the comment from the children and stopped for a while in the certain page to give a chance to the children to memorize and guess the next words. Furthermore, the researcher asked some 
questions to the students related to the story in the Big Book in order to help the students in comprehending the story.

The fourth activity in implementing Big Book as teaching media in this study was after reading activity. The activity was discussing the keyword in the story and helping the children to connect one concept with another concept. In implementing this study, it was done by relating their own experiences to the meaning of the story as well as their own language to the text indicated comprehension both the story and the function of the text. Then, the researcher and the students read the story together. The researcher gave stressing in the way to read and to give a correction about the way to read in comfortable way. If the researcher felt that the students understood enough about the text, the researcher allowed the students to read by themselves. If there was a mistake in the pronunciation, the researcher as the teacher helped students to read in the right way because if the students could read correctly it would make them more confident to read the text. In implementing this study, the students read the text loudly and correctly because they already remembered how to pronounce it while looking at the picture and hearing the researcher said in reading the text. This was in line with Lynch (2008) Big Book can be a media to give the children confidence in their ability to "read" it. By using Big Book in this activity, the students were able to see the text while it was being pointed to and read by the teacher. The students also could discuss the meaning of the story with their friends. Then, the researcher asked the students about the specific information that can be found in the text. It had purpose to confirm how far the students understood the story of the Big Book.

The fifth and last activity was close activity. Close activities were done with various types of interesting activities based on the area. According to Fisher (1991), there are some interesting activities for you learners such as; guessing word game, bolding the words game, arranging the words game, completing the missing words, coloring picture, cutting, folding, adhering, drawing, drama playing, imitating certain character in Big Book, drawing with finger, sand playing, painting, and putting number to the picture, arranging geometry, story telling, and many more. In implementing this activity, the researcher gave matching game for the first and second Big Book, arranging game for the third Big Book, completing the guessing words game for the fourth Big Book in order to check the students' reading comprehension of the story. In this activity, the students were very active to answer the question from the researcher, even students who usually less active in the classroom became enthusiastic while answering the researcher question. The researcher saw the cheerful expression from the students and realized that the students enjoyed the teaching and learning process in the classroom. This was in line with Morris et. al (2003) who pointed out that students age 7-9 years old have a positive attitude towards lessons using the Big Book, same as the subject of this study that were still in 9 years old.

The result of indicated that implementing Big Book as media in teaching reading comprehension on the third grade students had better effect than conventional media. Based on the discussion before, there were three factors that were made Big Book as media had better effect on students' reading comprehension rather than conventional media. First, teaching reading using Big Book as teaching media made students more active during the reading class activity rather than students taught by conventional media. Second, Big Book as teaching media attracted students' attention and encouraged students to read more. Third, Big Book as teaching media helped the students to construct the meaning of the text and it led them to have deeper understanding of the text given.

The role of the teacher in implementing Big Book is also important. Big Book as teaching media will not affect the students' reading comprehension if teacher cannot implement or use Big Book well. Teacher as the facilitators should learn and master how to use Big Book before teaching reading in the classroom because if teacher does not know how to use or implement this media, teacher will confuse in making lesson plan and relate this media with the material, and the objective of the teaching and learning process will not be achieved. That is why the role of the teacher is also important in this study.

Big Book was effective because students became more active in the teaching and learning process. It supported the result while implementing Big Book as teaching media, the students who were students who usually less active in the classroom became enthusiastic in each activity because the students involved in the learning process from the beginning until the end of the activities. It made the students more active in the classroom, especially when the students shared their opinion about the story and sometimes they asked about difficult words that they found from the Big Book. It was in line with the 
statement by Fahmi, Suhartono, \&Arifin (2013) who stated that one of the benefits of Big Book was increased students' participation in reading class activity.

According to Yuliana (2003), Young Learners are the learners in the age of 5 years old to 12 years old. In the age of 5 years old to 12 years old children are in the position of golden age. As the subject of this study, the students were still categorized as young learners because the students were still 9 years old and they were in their golden age. Further, according to Brendon (2012), children as young learners respond the language well through concrete things (visual thing) rather that an abstract one and children as young learners will enthusiastic if they are taught using fun activities or being involved in activities. Related with that, Big Book as teaching media got good respond from the students. It could be seen from the result of this study that the students were very enthusiastic in each activity because Big Book as teaching media provided the students fun activities that made the students involved in the learning process from the beginning until the end of the activities. This was in the line with the statement, Big Book are the large version of children's book and Big Book are considered to be one of the most effective ways of getting young children involved with print (Strickland and Morrow, 1990).

Big Book was effective as a teaching media because Big Book is large of colorful print with illustrations that allow whole classrooms to more understand about the content of the story or even stimulate students' imagination (Brown, 1980: 315).It was proven in this research that Big Book as media helped the students to construct the meaning of the text and it help them to have deeper understanding of the text given.It because Big Book has big pictures which help the students in constructing the meaning of the text (Karge-Bone, 1992 cited in Hall \& O'connor, 2006). Further, the result of the study showed that students' reading comprehension was developed during the treatment. That was in the line with the statement, Reading a big book is one of the activities used to facilitate students' comprehension of a story delivered by the teacher (Rahim \&Harun, 2010).

On the other hand, the control group was treated by using conventional media. The treatment for control group was also conducted eight times. The activity started by asking the students to make a group consisted of 4 students. Then, they were given a text and they were asked about the possible story from the title of the text. Then, the teacher read the story together with the students. After that, they were told to read the text with their group. After finished reading the text, the teacher asked about specific information of the story, meaning of some words, the synonym/antonym of some words to the students. Some students were active to answer the questions. In the end of the activity, they were given some questions related to the text.

During the implementations Big Book as teaching media for experimental group and conventional media for control group, the researcher observed that students from both groups showed different reaction in following the activity. In the control group, students' happiness only lasted for three meetings. On the fourth meeting until the last meeting, the students looked not excited in the learning process because students' expression showed that they were bored. After asking the reason to the students, some students said that they felt bored to read the text and answered the questions. Some others talked with their friends in the classroom. Some others said that they were not excited again to follow the story. Further, the students finally wanted to read story after the teacher gave some advices to the students and motivated them to read the story. In the implementation, the students in control just kept quiet while the teacher read the story because the students did really understand the story if not translated by the teacher. This factor made the students who were passive in the classroom became still passive and who were active in the classroom became less active in the teaching and learning process.

In contrast with the control group, the reactions of students in experimental group were very excited in following the activities. Starting from the first activity, the students seemed very excited to read the Big Book when the researcher showed the Big Book. On the first meeting, only some students were active in the learning process and several students were still shy to speak because they just knew the researcher who taught them in the class to replace their teacher for several meeting. On the second meeting, the students who were shy in the previous meeting started to speak, even the passive students in the classroom already started to speak too. On third until the last meeting, almost all of the students were active in asking and answering the questions related to the story and enthusiastic in sharing their opinion about the story and opinion about what the next page of the story would be. The researcher observed cheerful expression of the students and realized there were no students who seemed sleepy or did 
activities during teaching and learning process. It meant that students enjoyed the teaching and learning process in the classroom.

Considering the result of the study, the researcher could conclude that Big Book as media has been proven effective for teaching reading. It was found effective to be implemented for the third students of elementary school in south Bali since there was significance difference in the reading comprehension between third grade students of elementary school in south Bali were taught by using Big Book as teaching media and those who were taught by using conventional media. This statement also supported by the result of both descriptive and inferential statistical analysis of this study.

The result of this study supported the findings of some empirical studies. Fahmi, Suhartono, \&Arifin (2013) who conducted experimental research in improving students' reading comprehension using Big Book. The result of this result showed Big Book could improve fifth grade students' reading comprehension. The other research by Tatminingsih (2013), who conducted an action research in improving reading readiness of children in Kindergarten. She found that all children had a good improvement in their reading readiness by using Big Book. Furthermore, this current study was also in line with three studies. First, Mahayanti, Padmadewi, and Wijayanti (2017) who found that there was a significant effect of Big Book as media on students' reading comprehension at fourth grade of elementary school. Second, Mahayanti, Artini, and Jannah (2017) who found that there was a significant difference of reading comprehension achievement between students treated with Big Book as media and those treated using conventional media at fifth grade of elementary school. Third, Mahayanti and Asrina (2017) who found that there was a significant difference on the sixth grade students' reading comprehension between students taught by using Big Book as media and students taught by using conventional media.

Therefore, the result of the current study was in line to the researchers presented in the empirical review which found that Big Book as media had significant effect on reading comprehension of students. This study found that there was a significant effect of Big Book as media on students' reading comprehension at third grade of elementary school in south Bali.

Big Book as teaching media affects positively on reading comprehension of the third grade students of elementary school in south Bali, this statement had been tested and proven empirically by the researcher. The result of the study about students' reading comprehension taught by using Big Book as teaching media was better than those who were taught by using conventional media. Based on the result which the researcher got, Big Book can be one of the appropriate teaching media that can be implemented in improving students' reading comprehension in teaching and learning process.

Big Book as media can improve students' participation in the classroom. Further, Big Book as teaching media can attract students' attention and can encourage students to read more and it indicates that Big Book is appropriate for young learner as teaching media. Each activity in the implementation of Big Book as teaching media in the teaching and learning process influences students to be active in the classroom. The students enjoyed the learning process and motivated to read more in order to get better achievement. Moreover, Big Book as teaching media can help the students to understand the meaning of the text and help them to comprehend the text deeply.

\section{CONCLUSION}

The result descriptive statistical analysis and inferential statistical analysis that had been explained in previous chapter made the researcher could conclude the result of this study. First one, the result of descriptive statistical analysis showed that the mean score of experimental group was 80.5357 and the mean score of control group was 75.3571. It meant that the mean score of students in experimental group was significantly higher than the control group. It was indicated that reading comprehension of students in experimental group was better than reading comprehension of students in control group. Second one, the result of inferential statistical analysis showed the comparison between $t_{\text {obs }}\left(t\right.$ observed) and $t_{c v}(t$ critical value) was $2.181>2.0049$. It meant that the value of $t$-observed $\left(\mathrm{t}_{\mathrm{obs}}\right)$ was higher than the value of $\mathrm{t}$-critical value $\left(\mathrm{t}_{\mathrm{cv}}\right)$. These results indicated that the null hypothesis was rejected $(\mathrm{H} 0)$ and alternative hypothesis $(\mathrm{H} \alpha)$ was accepted. Moreover, it could be concluded that there was a significant effect of Big Book as teaching media on students' reading comprehension at third grade of elementary school in south Bali in academic year 2017/2018. 
Based on the result of the study, there are some suggestions that can be proposed by the researcher. First for teacher, the researcher recommends the teacher who teaches the young learners to use Big Book as teaching media in teaching reading English to improve students' reading comprehension because this media has unusual size which can attract the students' attention in teaching and learning process and also can influence the student to read more. In addition, Big Book also can stimulate students' participation through the activity while implementing this media as teaching media in the classroom. Second for students, the researcher recommends the students to use Big Book as learning media to help the students improve their reading comprehension in reading English. It is because this media has colorful picture in every pages that motivate the students to read Big Book and help them to have deeper understanding in reading the text. Third for other researchers, as this research is limited in the number of type Big Book use and also the time of the research, for research should be conducted on different and bigger population, and used more variation of Big Book in order to make the stronger empirical evidence of the important of Big Book. In addition, the research should be analyzed deeply in order to find out the other benefit of Big Book as teaching media in students' reading comprehension.

\section{REFERENCES}

Andi, W S. (2013). "Benefits of Using Media In Teaching Learning Activities". Retrieved May 19, 2018 from http://ndishoke.blogspot.com/2013/06/

benefits-of-using-media-in-teaching.html.

Brendon, Brendan. (2012). Characteristic of Young Learners. Retrieved from: http://brendabrendon.blogspot.co.id/2012/12/characteristicof-young-learners.html

Brown, H, Douglas. (1980). Principle of Language Learning and Teaching. New Jersey: Prective Hall Inc.

Fahmi, D. I., Suhartono, L. and Arifin, Z. "Improving Students' Reading Comprehension Using Big Book". (2014): 1-11. Print.

Fisher, B. (1991). Joyful Learning, A Whole Language Kindergarten. USA: Heinemann.

Hall, S. C., \& O'Connor, B. (2006). Using Big Book: Standards-Based Instructional Approach for Foreign Language Teacher Candidates in a PreK-12 Program. Foreign Language Annals, 493.

Harmer, J. (1998). How to Teach English. Cambridge: Pearson Education Limited.

Harmer, J. (2007). The Practice of English Language Teaching. Harlow: Longman.

Lynch, Priscilla. (2008). Using Big Books and Predictable Books. Scholastic:Canada Ltd.

Mahayanti, Artini, and Jannah .(2017). "The Effect of Big Book as Media in Teaching English at Fifth Grade Students based on the Syllabus in SD Laboratorium UNDIKSHA Singaraja". E-Journal

Mahayanti and Asrina. (2017). "The Use of Big Book as Media in Teaching English at Sixth Grade Students based on the Syllabus in SD Laboratorium UNDIKSHA Singaraja". E-Journal

Mahayanti, Nitiasih, and Wiraprasta. (2017). Developing Big Book as Media for Teaching English at Third Grade Students of Elementary School at SD Lab UNDIKSHA Singaraja in Academic Year 2017/2018. Ganesha University of Education.

Mahayanti, Padmadewi, and Wijayanti . (2017). "The Effect Of Big Book as Media on Students' Reading Comprehension at Fourth Grade of Elementary School in SD Laboratorium UNDIKSHA in Academic Year 20016/2017'. E-Journal.

Nambiar, M. (1991). Big Books for little readers: Works in the ESL classroom too. (Eric Document Reproduction Service No. ED 333736)

Nunan, D. (1999). Second Language Teaching and Learning. Boston: Heinle\&Heinle Publisher.

Rahim, N. A., \&Harun, N. I. (2010). Students' Perception Towards The Usage of the Big Book. Gading Business and Management Journal, 14

Seken, I Ketut. 2015. Introduction to Pragmatics; a Course Book for Beginners. Yogyakarta: GRAHA ILMU.

Strickland, D,S. and Morrow, L,M. (1990) Emerging teachers and writers: Sharing Big Books. Reading Teacher, 43, 342-343.

Tatminingsih, S. (2013). International Conference On Educational Research and Innovation (ICERI 2013 ). In Big Book, A Teaching Alternative For Improving Children's Reading Readiness In Kindergarten. Yogyakarta: UNY Press. 
Wahyuni, T. (2013). "The effectiveness of using picture series as media in teaching speaking of the first grade students of SMAN 1 Kampak". State Islamic College of Tulungagung. E-Journal

Yuliana. Teaching English to Young Learners through Songs 5 (2003): 62-66. Print. 